\title{
PENGEMBANGAN SDM RUMAH SAKIT DI TENGAH PANDEMI COVID-19 PADA RS. MEDIKA BSD
}

\author{
Muger Apriansyah ${ }^{1}$, Agrasadya $^{2}$, Ading Sunarto ${ }^{3}$, Laila Irawati', \\ Putri Nilam Kencana ${ }^{6}$ \\ Universitas Pamulang \\ Email: dosen01019@unpam.ac.id
}

\begin{abstract}
The purpose of this Community Service activity is to carry out one of the Tri Dharma of Higher Education and its main objective is to provide an overview of strategies that can be carried out in an effort to foster work motivation for current employees, especially employees of the Medika Hospital BSD Tangerang. In addition, it is hoped that with this community service, the existence of universities can make a major contribution to the development and application of science to the community. The method by which the activity is carried out is that we go directly to the PKM location, namely at the Medika Hospital BSD, which is located at Jl. Lieutenant Soetopo, No. 7, BSD Serpong, Kota Tangerang Selatan, Banten 15310. The results of community service obtained include increased motivation for employees to work harder and improve their competence during the Covid19 pandemic and the increased knowledge of employees at the Medika Hospital BSD Tangerang so that they have a good perspective on the importance of increasing and building self-motivation to work better and learn to be responsible in the present as their provision for life in the future. The knowledge gained in Community Service this time is expected to be able to provide new enthusiasm for lecturers in an effort to develop themselves in providing direction, delivery of material and motivation as well as contributing to the younger generation both in the school environment, campus, family and society at large.
\end{abstract}

Keywords: Human Resource Development, Hospital, Pandemic Covid-19.

\begin{abstract}
Abstrak
Tujuan dari kegiatan Pengabdian Kepada Masyarakat ini adalah untuk melaksanakan salah satu Tri Dharma Perguruan Tinggi dan tujuan utamanya adalah untuk memberikan gambaran strategi yang dapat dilakukan dalam upaya menumbuhkan motivasi kerja para karyawan saat ini, khususnya karyawan Rumah Sakit Medika BSD Tangerang. Selain itu diharapkan dengan pengabdian kepada masyarakat ini keberadaan perguruan tinggi dapat memberikan kontribusi besar kepada pengembangan dan penerapan keilmuan kepada masyarakat. Metode yang kegiatan yang dilaksanakan adalah kami mendatangi langsung ke lokasi PKM yaitu di Rumah Sakit Medika BSD Tangerang yang beralamat di Jl. Letnan Soetopo, No. 7, BSD Serpong, Kota Tangerang Selatan, Banten 15310. Hasil pengabdian kepada masyarakat yang diperoleh yakni bertambahnya dorongan motivasi para karyawan untuk bekerja lebih giat dan meningkatkan kompetensinya selama
\end{abstract}


masa pandemic Covid-19 ini dan bertambahnya keilmuan para karyawan di Rumah Sakit Medika BSD Tangerang agar mereka memiliki cara pandang yang baik tentang pentingnya meningkatkan dan membangun motivasi diri untuk bekerja lebih baik lagi dan belajar bertanggung jawab pada masa kini sebagai bekal mereka untuk kehidupan di masa yang akan daatang. Ilmu yang didapatkan pada Pengabdian Kepada Masyarakat kali ini diharapkan mampu memberikan semangat baru bagi dosen dalam upaya mengembangkan diri memberikan pengarahan, penyampaian materi dan motivasi serta berkontribusi bagi generasi muda baik di dalam lingkungan sekolah, kampus, keluarga dan masyarakat secara luas.

\section{Kata Kunci: Pengembangan SDM, Rumah Sakit, Pandemic Covid-19}

\section{A. PENDAHULUAN}

Rumah Sakit Medika BSD merupakan Rumah Sakit Umum Swasta yang terletak di daerah serpong, Tangerang yang didirikan pada 7 Desember 2009. Layanan yang ditawarkan Rumah Sakit Medika BSD berupa; Poliklinik Umum \& Spesialis, IGD dan Farmasi. Memiliki Visi menjadi pilihan utama untuk pelayanan kesehatan dengan Misi memberikan pelayanan kesehatan yang berkualitas kepada pasien. Rs Medika BSD berlokasi di pusat kota BSD City, Serpong, Tangerang. Menempati area seluas $12.000 \mathrm{~m} 2$, gedung RS Medika BSD terdiri dari 7 lantai, merupakan rumah sakit yang menawarkan pelayanan kesehatan yang komprehensif melalui pelayanan Diagnostik, Kuratif, Terapi, Rehabilitasi, Radiologi serta berbagai layanan medis dan bedah lainnya. RS Medika BSD siap untuk memberikan pelayanan kesehatan kepada masyarakat luas, para eksekutif dan perussahaan-perusahaan dengan multi-disiplin layanan Spesialis, personalisasi perawatan pasien dengan teknologi mutakhir

Dalam hal sumber daya manusia, rumah sakit merupakan organisasi padat SDM karena banyaknya macam profesi dan jumlah tenaga kerja yang bergerak di dalamnya. Sumber daya yang ada di dalam sebuah rumah sakit terdiri dari tenaga kesehatan (meliputi dokter, perawat, apoteker, analis, ahli gizi, fisioterapis, radiografer, perekam medis) dan juga non tenaga kesehatan (keuangan, administrasi, personalia, keamanan, dan sebagainya). Dalam sistem manajemen rumah sakit, diperlukan sebuah sistem / model untuk mengelola sumber daya manusia yang ada di dalamnya. Terdapat 7P yang perlu dikelola secara baik.

$7 \mathrm{P}$ dalam model manajemen sumber daya manusia tersebut terdiri dari : 1 . Perencanaan. Perencanaan merupakan aktivitas proses penetapan apa yang ingin dicapai dan pengorganisasian sumber daya untuk mencapainya. Perencanaan sumber daya manusia meliputi jenis tenaga yang dibutuhkan dan berapa jumlahnya yang disesuaikan dengan lingkup pelayanan yang akan dilaksanakan. Jumlah tenaga yang diperlukan tentunya harus disesuaikan dengan tipe layanan rumah sakit terkait. Lingkup pelayanan ini biasanya ditentukan berdasarkan tipe rumah sakitnya. Lingkup pelayanan rumah rumah sakit (tipe $\mathrm{A} / \mathrm{B} / \mathrm{C} / \mathrm{D})$ mempunyai standar minimal. Misalnya untuk rumah sakit tipe $\mathrm{D}$ minimal pelayanan medisnya adalah 2 besar. Dengan adanya ketentuan tersebut maka tentu saja perencanaan SDM di rumah sakit tipe D akan berbeda dengan tipe yang lain. 2. Penerimaan Penerimaan karyawan merupakan tahap yang sangat kritis dalam manajemen SDM. Bukan saja karena biaya proses penerimaan karyawan sangat mahal melainkan juga diperlukan menyeleksi karyawan baru. Karyawan juga merupakan wajah dari perusahaan/organisasi tersebut sehingga karyawan yang baik tentunya akan mencerminkan citra yang baik untuk rumah sakit tersebut. Rumah sakit merupakan sebuah organisasi pelayanan jasa yang sifat 
produknya intangible (tidak bisa dilihat) tetapi bisa dirasakan. Pelayanan ini hampir pasti langsung diberikan oleh karyawan (bukan oleh mesin/atau alat). Sehingga sikap, perilaku dan karakter karyawan sangat mempengaruhi kualitas jasa yang diberikan. Oleh karena itu, proses penerimaan SDM rumah sakit harus memperhatikan sikap, perilaku dan karakter calon karyawan. 3. Pengembangan Kompetensi SDM harus dikembangkan secara terencana sesuai dengan pengembangan usaha agar menjadi kekuatan untuk mendukung pencapaian tujuan organisasi. Di rumah sakit diperlukan karyawan yang selalu meningkatkan kompetensinya karena teknologi, ilmu pengetahuan tentang pelayanan kesehatan berkembang sangat pesat dari waktu ke waktu. Adanya peralatan baru, metode perawatan yang berubah merupakan contoh betapa perlunya pengembangan kompetensi. Pengembangan kompetensi ini antara lain pendidikan dan pelatihan, pemagangan di rumah sakit lain, rotasi, serta mutasi. 4. Pembudayaan. Budaya perusahaan merupakan pondasi bagi organisasi dan pijakan bagi pelaku yang ada di dalamnya. Budaya organisasi adalah norma - norma dan nilai - nilai positif yang telah dipilih menjadi pedoman dan ukuran kepatutan perilaku para anggota organisasi. Kompetensi yang dimiliki oleh karyawan rumah sakit harus diimbangi dengan kecerdasan emosional dan kebiasaan positif. Pembentukan budaya organisasi merupakan salah satu lingkup dalam manajemen SDM. 5. Pendayagunaan. The right person in the right place merupakan salah satu prinsip pendayagunaan. Bagaimana kita menempatkan SDM yang ada pada tempat atau tugas yang sebaik - baiknya sehingga SDM tersebut bisa bekerja secara optimal. Ada SDM yang mudah bergaul, luwes, sabar tetapi tidak telaten dalam hal keadministrasian. Mungkin SDM ini cocok di bagian yang melayani publik daripada bekerja di kantor sebagai administrator. Lingkup pendayagunaan ini adalah mutasi, promosi, rotasi, perluasan tugas dan tanggung jawab. 6. Pemeliharaan SDM merupakan manusia yang memiliki hak asasi yang dilindungi dengan hukum. Perusahaan/organisasi berkewajiban memperlakukan pegawai dengan baik sebagaimana hak yang dimilikinya sesuai dengan peraturan yang ada. SDM perlu dipelihara dengan cara misalnya pemberian gaji sesuai standar, jamisan kesehatan, kepastian masa depan, membangun iklim kerja yang kondusif, memberikan penghargaan atas prestasi dan lain - lain. 7. Pensiun Seiring berjalannya waktu, SDM akan memasuki masa pensiun. Rumah sakit harus menghindari kesan" habis manis sepah dibuang", dimana ketika karyawannya sudah masa pensiun kemudian dikeluarkan begitu saja. Karena itu sepatutnya rumah sakit mempersiapkan karyawannya agar siap memasuki dunia purna waktu dengan keyakinan. Ada banyak hal yang bisa disiapkan yaitu pemberikan tunjangan hari tua yang akan diberikan pada saat karyawan pensiun, pemberikan pelatihan - pelatihan khusus untuk membekali calon purnakarya.

Covid-19 telah mengubah banyak hal dalam sekejap. Tidak pernah ada dalam sejarah manusia modern suatu pandemi berlangsung dan menjalar secara cepat seperti Covid-19. Karena itu, setiap peristiwa, respons, dan reaksi seringkali juga bersifat unprecedented . Baik itu pada level individual, komunitas yang paling kecil, sampai dengan negara bangsa. Organisasi dan korporasi juga dipaksa untuk dapat beradaptasi dengan tingkat ketidakpastian yang sangat tinggi. Pandemi telah memaksa kita semua untuk bersiasat secara cepat, tetapi sekaligus akurat. Pemerintah telah menunjukkan kecepatan bersikap yang ditandai dengan realokasi anggaran APBN untuk difokuskan pada penanganan dampak yang ditimbulkan dari pandemi, baik secara sosial maupun ekonomi. Anggaran sebesar kurang lebih Rp405 triliun digeser untuk keperluan tersebut. Perubahan cara dan pola kerja yang berfokus pada physical distancing telah memaksa sebagian besar aktivitas di ruang publik dan perkantoran menjadi berkurang signifikan. Kegiatan bisnis dan pemerintahan bergeser dari yang bersifat centric di kantong-kantong bisnis dan pemerintahan menjadi menyebar di rumah-rumah warga.

Pembatasan Sosial Berskala Besar (PSBB) yang diberlakukan oleh pemerintah dan dijalankan sejumlah pemerintah daerah di kota-kota besar dan menengah di Indonesia 
membuat aktivitas bisnis ikut berubah. Pertanyaannya, apakah pola kerja yang berubah tersebut telah menurunkan secara signifikan tingkat produktivitas para karyawan di setiap korporasi dan organisasi pemerintahan? Bagaimana pula pola kerja karyawan yang selama pandemi berubah dari yang sifatnya time based menjadi output based karena mereka harus bekerja jauh dari kantor?

Dalam korporasi yang berhubungan dengan kepentingan publik, ketika work from home (WFH) diberlakukan, korporasi atau organisasi harus mendefinisikan terlebih dahulu pelayanan ataupun kegiatan bisnis yang sifatnya kritikal tetap berjalan. Sementara unit-unit lain yang sifatnya mendukung dapat dikerjakan dari mana saja, termasuk bekerja dari rumah atau work from home. Ketika memasuki kondisi new normal, apakah pola bekerja jarak jauh akan hilang dan orang akan berbondong-bondong untuk masuk ke kantor?

Selama masa pandemi dan orang dituntut untuk bekerja dari rumah, produktivitas tetap dapat dijaga dan koordinasi tetap dapat dilakukan dengan bantuan teknologi. Bahwa ada isu-isu atau hambatan yang berkaitan dengan keamanan data, itu tidak akan menjadi penghalang besar karena secara faktual, mekanisme bekerja dari jarak jauh tanpa kehilangan produktivitas telah terbentuk selama masa pemberlakuan PSBB. Karena itu, upaya pemerintah untuk mengembalikan kondisi pada new normal justru dapat menjadi momentum bagi perusahaan untuk menata ulang sistem kerja di kantor-kantor, sembari mengumpulkan seluruh best practices yang diperoleh karyawan yang selama ini menjalankan pola kerja work from home . Demikian juga penghalang-penghalang yang selama ini muncul dengan adanya work from home. Dengan cara itu, maka upaya untuk menuju new normal dapat menjadi momentum bagi perusahaan untuk menata ulang sumber daya yang mereka miliki dengan membangun suatu iklim kerja baru yang menyesuaikan dengan kondisi new normal tersebut.

Harus disadari, yang dimaksud dengan kondisi new normal bukanlah kondisi di mana tidak ada lagi virus Covid-19 di tengah-tengah kita. Mengharapkan itu terjadi adalah sesuatu yang mustahil. New normal adalah kondisi di mana setiap orang harus menyesuaikan diri dengan kondisi baru di mana ancaman virus itu tetap nyata dan bisa menghinggapi siapa saja. Yang dibutuhkan adalah kewaspadaan yang makin tinggi, kedisiplinan yang makin kuat, dan dalam konteks tersebut, korporasi harus juga dapat menjadi salah satu garda depan untuk menciptakan kondisi new normal tersebut. Rumah Sakit sebagai sebuah organisasi yang bergerak dalam bidang jasa memiliki hubungan yang sangat erat dengan pengelolaan sumber daya, baik dalam bentuk sarana dan prasarana maupun manusianya.

Tujuan dari PKM ini adalah memberikan gambaran strategi yang dapat dilakukan dalam upaya mengembangkan SDM dalam menghadapi Covid-19. Kemudian dipaparkan pula tentang hambatan yang dihadapi dalam penerapan strategi tersebut, serta manfaatnya. Diharapkan hasil dari PKM ini juga dapat menjadi inspirasi bagi para karyawan agar semakin termotivasi agar menjadi SDM yang maju dan kreatif di tengah pandemic Covid-19. Dengan begitu, hambatan dalam pelaksanaan pekerjaan dapat teratasi dengan baik.

Dengan mempertimbangkan latar belakang yang telah dijelaskan diatas kami berinisiatif untuk membentuk pengabdian kepada masyarakat bagi karyawan yang ada di RS Medika BSD khususnya dalam program dorongan motivasi agar dapat mengembangkan kompetensinya, semakin maju dan kreatif selama masa pandemic Covid-19 saat ini.

\section{B. METODE PELAKSANAAN}

Metode kegiatan yang dilakukan adalah dengan melakukan kunjungan langsung ke Rumah Sakit Medika BSD, Tangerang yang beralamat di Jl. Letnan Soetopo, No. 7, BSD Serpong, Kota Tangerang Selatan, Banten 15310. Metode yang digunakan dalam kegiatan PKM ini adalah sebagai berikut : 
1. Mengidentifikasi permasalahan pada saat awal kegiatan untuk merumuskan permasalahan dan sebagai bahan untuk perancangan pemberian materi penyuluhan kepada peserta didik

2. Survei ke lapangan ke di ke Rumah Sakit Medika BSD Tangerang sebagai objek tempat dilaksanakannya kegiatan PKM. Selanjutnya melakukan sesi wawancara, diskusi dan Tanya jawab dengan pihak Rumah Sakit untuk mengidentifikasi permasalahan yang ada didalam lingkungan peserta didik.

3. Melakukan studi literasi sebagai pedoman materi didalam penyampaian penyuluhan selama proses kegiatan berlangsung.

4. Pelaksanaan kegiatan Pengabdian Pada Masyarakat ini dilakukan dengan menggunakan metoda ceramah, tutorial, dan diskusi

\section{HASIL DAN PEMBAHASAN}

\section{Tahap Persiapan}

Sebelum melaksanakan Pengabdian Kepada Masyarakat kami selaku Dosen Universitas Pamulang melakukan pra-survey ke tempat yang akan menjadi tujuan PKM kami yakni Rumah Sakit Medika BSD Tangerang. Penyuluhan ini bertujuan agar para karyawan yang ada di Rumah Sakit ini dapat meningkatkan motivasi kerjanya di masa pandemic Covid-19 saat ini. Selanjutnya team PKM yang terdiri dari lima orang dosen UNPAM melakukan Forum Group Discussion (FGD) untuk mempersiapkan pelaksanaan Pengabdian Kepada Masyarakat (PKM) untuk tanggal 14-16 Oktober 2020.

\section{Tahap Pelaksanaan Pengabdian Kepada Masyarakat}

Pelaksanaan Pengabdian Kepada Masyarakat di Rumah Sakit Medika BSD Tangerang dilaksanakan pada tanggal 14-16 Oktober 2020. Kegiatan dilaksanakan di Rumah Sakit Medika BSD Tangerang yang beralamat di Jl. Letnan Soetopo, No. 7, BSD Serpong, Kota Tangerang Selatan, Banten 15310. Kegiatan ini terlaksana atas kerjasama atau MoU Universitas Pamulang dengan Rumah Sakit Medika BSD Tangerang. Kegiatan PKM ini mengambil judul "Pengembangan SDM Rumah Sakit Di Tengah Pandemi Covid-19 Pada RS Medika BSD"

\section{Tahap Penyuluhan}

Untuk melaksanakan kegiatan PKM ini digunakan beberapa metode penyuluhan yaitu sebagai berikut :

a. Metode Ceramah $\rightarrow$ Metode yang digunakan dalam penyuluhan ini yaitu penyuluhan dengan memberikan ceramah atau presentasi dengan judul "Pengembangan SDM Rumah Sakit Di Tengah Pandemi Covid-19 Pada RS Medika BSD"

b. Metode Diskusi Dan Tanya Jawab $\rightarrow$ Setelah sesi pemberian materi selesai, maka dilanjutkan dengan sesi diskusi dengan tanya jawab. Hasil yang didapatkan para karyawan sangat antusias untuk bertanya terkait bagaimana cara untuk meningkatkan motivasi kerja di divisinya masing-masing di masa pandemic Covid-19 saat ini. Untuk peserta yang aktif dan berani bertanya kami berikan reward berupa cinderamata dari Universitas Pamulang dan sumbangsih dari dosen-dosen Universitas Pamulang.

c. Metode Simulasi $\rightarrow$ Penyuluhan ini juga menggunakan metode simulasi, sehingga peserta langsung dapat mempraktekan apa yang sudah disampaikan. Apabila ada kendala yang dirasakan maka langsung dibantu pada saat pelaksanaan PKM. Simulasi ini penting dilakukan untuk mengetahui seberapa 
besar tingkat pengetahuan dan ilmu yang diserap oleh para karyawan selama penyuluhan.

\section{KESIMPULAN DAN SARAN}

\section{Kesimpulan}

Pelaksanaan kegiatan Pengabdian Kepada Masyarakat oleh Lembaga Penelitian dan Pengabdian Masyarakat (LPPM) Universitas Pamulang yang dilakukan oleh dosen-dosen Program Studi Manajemen telah berjalan dengan lancer dan mendapat sambutan positif dan hangat dari tempat pelaksanaan kegiatan PKM di Rumah Sakit Medika BSD Tangerang. Harapan kami selaku dosen dengan adanya kegiatan PKM ini dapat menambah ilmu yang bermanfaat dalam hal sikap disiplin dan tanggung jawab.

Dalam laporan kegiatan PKM ini meungkin banyak kekurangan yang ada, untuk itu kami berharap masukan dan kritikan dalam rangka perbaikan untuk kegiatan PKM selanjutnya. Semoga kegiatan PKM ini dapat bermanfaat bagi masyarakat di sekitar Universitas Pamulang dan lainnya. Dengan adanya kegiatan Pengabdian Kepada Masyarakat (PKM) ini, diharapkan peserta dapat mengaplikasikan ilmu yang telah mereka peroleh dalam kehidupan sehari-hari. Dan pada akhirnya, ilmu tersebut dapat dirasakan manfaatnya oleh peserta sendiri dan lingkungan di sekitarnya, khususnya lingkungan RS Medika BSD Tangerang.

Akhirnya, kami mengucapkan banyak terimakasih kepada seluruh pihak yang telah mendukung dan berkontribusi dalam kegiatan PKM ini dan kami memohon maaf apabila dalam kegiatan PKM ini banyak ditemukan kekurangan dan kesalahan

\section{Saran}

Berdasarkan hasil kegiatan PKM yang sudah dilakukan, maka kami dari team Dosen Universitas Pamulang memberikan saran yaitu sebagai berikut :

1. Untuk pihak pengelola RS Medika BSD Tangerang, adalah hendaknya lembaga memfasilitasi karyawan dengan pelatihan (training) secara berkala tentang bagaimana strategi pengembangan SDM dalam menghadapi pandemic Covid-19 agar menjadi SDM kreatif untuk menghadapi kondisi dan situasi pandemic seperti sekarang ini sehingga SDM semakin kompeten dalam melaksanakan tugas sesuai dengan jobdesk masing-masing dan memberikan dampak positif bagi kemajuan RS Medika BSD Tangerang.

2. Adanya kontribusi dari pihak Universitas untuk bisa memberikan fasilitas dalam pelayanan kepada masyarakat dalam bentuk sarana dan prasarana.

\section{DAFTAR PUSTAKA}

Aulina, C. N. (2018). Penerapan Metode Whole Brain Teaching dalam Meningkatkan Motivasi Belajar Anak Usia Dini. Jurnal Obsesi : Jurnal Pendidikan Anak Usia Dini, 2(1), 1 .

Damanik, B. E. (2019). Pengaruh Fasilitas Dan Lingkungan Belajar Terhadap Motivasi Belajar. Publikasi Pendidikan, 9(1), 46.

Dumilah, R., Sunarto, A., Solihin, D., \& Maulida, H. (2020). PELATIHAN PEMANFAATAN MEDIA SOSIAL UNTUK PROMOSI USAHA ATAU BISNIS BAGI SISWA. DEDIKASI PKM, 1(1), 26-33. 
Emda, A. (2018). Kedudukan Motivasi Belajar Siswa Dalam Pembelajaran. Lantanida Journal, 5(2), 172.

Fathurrahman. (2020). Penggunaan Metode Pembelajaran Role Playing Dalam Menumbuhkan Motivasi Belajar Pada Pembelajaran Sejarah.

Hasanah, U. (2015). Hubungan Lingkungan Sekolah dan Motivasi Belajar Dengan Hasil Belajar IPS Siswa Kelas VIII Di MtsN Amuntai. Jurnal Socius, 4 (2).

Mardiana, S., Supriyatna, W., Hasanah, Y. M., Zakaria., \& Indirasari, I. (2010). Optimalisasi Anggaran Keuangan Di Masa Pandemi Pada Desa Cicalengka Kabupaten Pagedangan Tangerang. DEDIKASI PKM. 1 (3).

Peraturan Menteri Kesehatan Republik Indonesia No.9 Tahun 2020 tentang Pedoman Pembatasan Sosial Berskala Besar Dalam Rangka Percepatan Penanganan Covid-19

Qurbani, D., Mardiana, S., \& Nugroho, R. D. (2020). Meningkatkan Minat Dan Potensi Generasi Milenial Khususnya Siswa-Siswi SMK Darussalam Untuk Memulai Bisnis Online Dengan Sistem Dropship. DEDIKASI PKM. 1 (3).

Siregar, H. I. (2015). Peningkatkan Motivasi Belajar Siswa Dalam Pembelajaran Microsoft Excel Dengan Menggunakan Metode Tutor Sebaya Di Kelas VIII-D SMP Negeri 1 Batangkuis. SCHOOL EDUCATION JOURNAL PGSD FIP UNIMED, 4(1), 127-140.

Solihin, D., Susanto, N., Setiawan, R., Ahyani, \& Darmadi. (2020). Penerapan Strategi Pemasaran Sebagai Upaya Meningkatkan Usaha Kecil Dan Menengah Warga Di Kelurahan Paninggilan Utara Ciledug. ABDI LAKSANA, 1(3), 351-355.

Solihin, D., Prasetiyani, D., Sari, A. R., Sugiarti, E., \& Sunardi, D. (2020). Pemanfaatan Botol Bekas Sebagai Penyaring Air Bersih Sederhana Bagi Warga Desa Cicalengka Kecamatan Pagedangan Kabupaten Tangerang. DEDIKASI PKM, 1(3), 98-102.

Suryani, M. (2015). Meningkatkan Motivasi Belajar Pembelajaran Untuk Siswa Kelas V SD Negeri 04 Pasar Pandan Air (PPA) Mati Solok Melalui Metode Inquiry. Inovasi Pembelajaran Berbasis Riset di Sekolah Dasar, 1 (1).

Sunarto, A. (2020). Pengembangan Sumber Daya Manusia dengan Berbasis Inovasi Untuk Menghadapi Revolusi Industri 4.0. Jurnal Ilmiah MEA (Manajemen, Ekonomi, dan Akuntansi). 4 (2).

Syah, R. H. (2020). Dampak Covid-19 pada Pendidikan di Indonesia: Sekolah, Keterampilan, dan Proses Pembelajaran. SALAM: Jurnal Sosial dan Budaya Syar-i, 7(5). 